\title{
Ownership and Capital
}

\author{
Jacek Tittenbrun \\ Department of Sociology, Faculty of Social Sciences, Adam Mickiewicz University, \\ 1 Wieniawskiego Str., Poznań, Poland \\ E-mail address: jacek@amu.edu.pl
}

\begin{abstract}
The paper sets out to explore the relationship between two key economic concepts. To begin with, the notion of economic ownership is examined, leading to a distinction of two basic approaches. A case is made for a rent-based perspective on ownership and against its treatment as control. It is from this vantage point that in the second part of the paper a number of classic theories of capital are analysed, as based on Frank Fetter's review article.
\end{abstract}

Keywords: capital; ownership; rent, Austrian school; Marx; Bohm-Bawerk; Joan Robinson; Veblen

JEL code: B 630, P140

\section{INTRODUCTION}

Capital and ownership are arguably two key economic categories, dealt with by many classics of political economy. This tradition notwithstanding, their relation is far from clear.

A RENT NOTION OF OWNERSHIP to begin with, it is necessary to elucidate the concept of ownership, which itself is ambiguous. First, property can be viewed in legal and economic terms.i But even restricting oneself to the latter interpretation, two basic approaches can be distinguished. "private property is about an individual decision maker who directs resource use" (Heller 2008: 25).

Similarly, in one of his polemics with market socialism Hayek writes: "If the community is the owner of all material resources of production, somebody will have to exercise this right for it, at least in so far as the distribution and the control of the use of these resources is concerned" (1989: 135). But, a few sentences later, it turns out that this "central authority would simply have rights of ownership of all real resources" (Hayek, 1989: 135). It is one thing, of course, to attribute ownership of the means of production to the community, and quite another to vest it in the state, the centre or some other institution. Moreover, although Hayek is not completely clear on this point, he seems to equate ownership with decision-making or power over the means of production. In the present writer's opinion, this notion is erroneous, as it refers to consequences or preconditions of what Berle and Means call beneficial ownership (1969: 8), and not to this ownership as such. To argue that ownership consists in either "the power to assign the means of production to given uses or in the power to dispose of the products obtained" (Poulantzas, 1979: 18) is like staging Hamlet without Hamlet. Making decisions determining the use of the object is not the same thing as actually benefiting from that use. It is 
not the same thing also in the sense that those who exercise control over given assets need not be those who enjoy the fruits of these assets. The above argument applies even more explicitly to Mises, who expressly states that "ownership is the right of disposal" (1936: 517).

That this treatment is mistaken, can be most easily shown on a number of specific exaamples. The circumstance that an executive of a public library makes a decision where concretely, say, Russian literature should be stored, and which room should accumulate English fiction and poetry and so on and so forth does not, to be sure, transform her into an owner of these resources and the building itself. Similarly, while city authorities may take a decision that a definite street must be closed to traffic, this does not render them private owners of the street involved...the list of such illustrations of our point might be multiplied.

What lies at the heart of this "rent" analytical framework is that the benefits inherent in the ownership of the factors of economic activity always are, to a lesser or larger extent, gratuitous. The adjective 'gratuitous' derives from the Latin word gratuitus, meaning free, freely given, spontaneous.

It is in these terms that Marx proceeds in "Capital" (vol. I, ch. 7), using a number of examples from modern capitalism, albeit it has to be stressed that the basic nature of economic ownership is universal, i.e. present in other economic formations of society as well. This is, incidentally, emphasised by marx in, amongst others, the following statement:

The soil (and this, economically speaking, includes water) in the virgin state in which it suppliesman with necessaries or the means of subsistence ready to hand, exists independently of him, and is the universal subject of human labour. All those things which labour merely separates from immediate connexion with their environment, are subjects of labour spontaneously provided by Nature. Such are fish which we catch and take from their element, water, timber which we fell in the virgin forest, and ores which we extract from their veins.

It is true that this extraction of ores, coal, crude oil and other mineral deposits Always require some expenditure of human labour power. But can even the greatest effort of a worker equate with millions of years required for the natural processes to produce these forms of wealth? If the crucial aspect of economic property is apparent in the case of even transhistorically understood work, the more this is the case in the most developed system of production and labour, including exploitation of nature itself, as marx in "Capital" (vol. I, ch. 15) points out: that the productive forces resulting from co-operation and division of labour cost capital nothing. They are natural forces of social labour. So also physical forces, like steam, water, \&c., when appropriated to productive processes, cost nothing. But just as a man requires lungs to breathe with, so he requires something that is work of man's hand, in order to consume physical forces productively. [...]

After making allowance, both in the case of the machine and of the tool, for their average daily cost, that is for the value they transmit to the product by their average daily wear and tear, and for their consumption of auxiliary substance, such as oil, coal, and so on, they each do their work gratuitously, just like the forces furnished by Nature without the help of man. The greater the productive power of the machinery compared with that of the tool, the greater is the extent of its gratuitous service compared with that of the tool. In modern industry man succeeded for the first time in making the product of his past labour work on a large scale gratuitously, like the forces of Nature.

Ownership benefits are in fact inherent in the very nature of the capitalist firm. According to Ronald Coase (1973), there are a number of transaction costs to using the market; the cost of obtaining a good or service via the market is actually more than just the price of the good. Other costs, including search and information costs, bargaining costs, keeping trade secrets, and 
policing and enforcement costs, can all potentially add to the cost of procuring something with a firm. By producing internally, firms avoid these costs.

From this vantage point then, Coase's theory of transaction costs may be seen as the next chapter in the treatise on ownership, began by Marx, Simmel and others. In his seminal treatise on money the latter emphasised the rent-like, gratuitous essence of ownership, which he termed superadditum and exemplified as follows: "price that is fixed, the absolutely equal price, is the superadditum of wealth - a tax on the poor. The donum superadditum denotes a gift of God that is superadded to those gifts" (1990; 1997: 257$)$.

\section{CAPITAL}

The issue of the close relationship of the two aforementioned concepts has been repeatedly touched on in our preceding discussion of the various non-economic forms of capital. These hints, of course, testify perhaps to the underlying connection of ownership and capital as a component of the economy.

It is perhaps interesting to find out what the take on this issue of the author of "Capital" was; now, Marx regarded both capital and wage-labour as "forms of property", and he explained that „to couch those relations in which capital and wage-labour are present as property relations, one needs only to frame the relationship of the two parties in the process of augmenting value as a process of appropriation" (Marx 1980: 483, 464).

Interestingly, similar views are also held by some other unorthodox economists.

At the turn of the twentieth century, J. B. Clark and Bohm-Bawerk were consciously countering Marx's theory that the return to capital involved exploitation of labour. Clark's response, that wages and interest were simply prices stemming from the respective marginal products of labour and capital, is best expressed in his famous claim that "what a social class gets is, under natural law, what it contributes to the general output of industry" (Clark, 1891: 312). Thorstein Veblen disputed Clark's marginal productivity theory, however, arguing instead that profit was institutionally grounded in the social power of the capitalists that enabled them to appropriate the technological achievements of the society as a whole. Even more to the point and in line with the rent treatment of ownership laid out above, he "owners of corporate securities which represent free income", adding that "these large earnings (free income) have been capitalISEd" (Veblen 2001: 11).

Joan Robinson argued - citing Veblen and alluding to Marx - "that the meaning of capital lay in the property owned by the capitalist class, which confers on capitalists the legal right and economic authority to take a share of the surplus created by the production process" (Cohen, Harcourt 2003: 211).

As far as Marx is concerned, it is interesting that he already in his early work approached the two concepts in question the same way, defining in the chapter on "Capital" in his "Economic and Philosophic Manuscripts of 1844" (1959) "capital" as "private property in the products of other men's labour".

Interestingly, similar views are also held by some other unorthodox economists.

At the turn of the twentieth century, J. B. Clark and Bohm-Bawerk were consciously countering Marx's theory that the return to capital involved exploitation of labour. Clark's response, that wages and interest were simply prices stemming from the respective marginal products of labour and capital, is best expressed in his famous claim that "what a social class gets is, under natural law, what it contributes to the general output of industry" (Clark, 1891: 312). Veblen disputed Clark's marginal productivity theory, arguing instead that profit was 
institutionally grounded in the social power of the capitalists that enabled them to appropriate the technological achievements of the society as a whole.

Robinson argued - citing Veblen (1908) and alluding to Marx - that the meaning of capital lay in the property owned by the capitalist class, which confers on capitalists the legal right and economic authority to take a share of the surplus created by the production process. (Cohen, Harcourt 2003: 211).

It is worthwhile to examine economic conceptions of capital through the prism of their relationship, if any, to ownership.

The concept of capital holds a central place in every economic system, and on its treatment have always depended the leading categories in the theory of economics, All agree, whatever definition may be held, that! this is increasingly "a capitalistic age," The place, therefore, of the concept in all practical problems is growing more and more dominant; and a better definition of it is the most urgent need of the abstracter branch of economic science. (Fetter 1900). His point of departure is the Positive Theory of Capital of Böhm-Bawerk, which was given to the English reading public in 1891.

The aforementioned scholar provided a useful account of most significant conceptions of capital in modern economics that will constitute our source material.

Böhm-Bawerk undertook in his two large volumes to deal thoroughly with the theories of interest, and, to do so, was led to deal with the concepts of capital; for, thought he, it is capital for which interest is paid. However much he disputed the relation of production and interest, he had no doubt, in undertaking his study, as to the relation of capital and interest, Interest is the yield of capital in the broader sense, and capital the source of interest. (Fetter 1900).

If we were to treat this notion of capital as final, it would have to be considered as involving the pars pro to fallacy. This is to say, certain forms of capital in fact yield interest, but it is by no means its universal attribute. Nevertheless, it is significant that the aforementioned Austrian economist associates the notion of capital with that of rent, as our own theory would have it. Obviously, this implies that one does not accept all that ideological rhetorics about rewards for risk, waiting, and so on. When one puts his or her money in a bank wherein these savings are government-guaranteed, one bears no risk whatsoever.

A more general view is that of Adam Smith's division [...] into consumption goods and capital that brings an income. Note, though, that this notion does not indicate the ultimate source of that capital income. "Smith, in giving two varieties of the concept, - capital as a means of acquisition to the individual, and capital as a means of social production, - has in reality given, says Böhm-Bawerk, "two entirely independent conceptions, resting substantially on quite different foundations, and only connected externally by a very loose bond"(Fetter 1900). Then "the author abandons the historical order, and enumerates eight other variations of the concept: Hermann's "every durable foundation of a utility which has exchange value"; Menger's "groups of economic goods of higher rank [productive goods] now available to us for future periods," Kleinwächter's "tools of production"; Jevons's "sustenance of the labourer"; Marx's "instruments for the exploitation of the labourer"; Knies's goods available to satisfy wants in the future; Walras's goods which can be used more than once; McLeod's "value of the productive power contained in material goods. (Fetter 1900).

These are discussed more at length in Chapter V, the most important contentions being that the distinction between consumption goods and what he calls "the true instrument of production" is essential; that labour must not be confused with capital; "that land must for many important reasons also be kept distinct" (Fetter 1900).

The aforementioned passage shows both pluses and minuses of the Austrian economist's reasoning. It is true that, also in ownership terms, land must not be lumped together with capital 
because of the special role of nature as a source of free benefits. As to his view of labour, matters are a bit more complex. On the one hand, one cannot agree more with his claim that labour, and by extension, labour power must not be confused with capital.ii On the other side, however, Jevons's' notion of "sustenance of the labourer" that has prompted the aforementioned opinion, can be interpreted as referring to variable capital, called in this way because only labour power has the capacity to augment value, as distinct from non-human means of production which merely transfer their value on the product, and therefore are termed constant capital. But perhaps it would be too much to expect of someone that critical to Marx as the Austrian economist in question to accept the notion of surplus value, this Marxian hallmark.

The distinction between, in the parlance of modern economics, to categories of goods: consumption or consumer, and investment goods is also, in ownership terms, not that simple as it is on the surface. Whilst it is undeniable that, by and large, only one of the two can be an object of private ownership, whilst - as distinct from means of production - means of consumption, by and large, are personal property only, this is not the case in all instances. Namely, when a given consumer good is a means of money-making, be it through its sale, or using as a means of acquisition (e.g. the use of one's car as a taxi), it should be conceived of in terms of private property. It is, arguably, to this fact, that Böhm-Bawerk refers distinguishing between the wider and narrower conceptions, acquisitive (private) and productive (social) capital. Of the former he says: "Capital in general we shall call a group of Products which serve as means to the Acquisition of Goods. Under this general conception we shall put that of Social Capital as narrower conception. The problem of interest, he thinks, is connected with private or acquisitive capital, not necessarily with social or productive capital" (Fetter 1900). A similar idea underlies Hermann's aforementioned notion of capital, and thus private property as "every durable foundation of a utility which has exchange value";

In Fetter's reading this similarity of the above-mentioned Austrian conception to what has been called above rent theory of ownership is even more pronounced as he writes about "capital in general," or private capital, embracing all social capital and, in addition, such consumption goods as are let for hire" (1900).

As Fetter reports further:

The more usual point of attack on the author has been his interest theory, not his capital concept, which has been far less questioned, in fact, has usually been accepted as flawless. Some protests, however, have already been raised against it; and, although it is still the dominant concept, discontent with this and other features of the older economic thought has been spreading. The earnest teacher, using the available text-books, and attempting to correct their treatment in accord with recent criticisms, is in despair. To one who has watched the course of the discussion it might seem that the service of Böhm-Bawerk's work, so far as it touches the capital concept, lay not in settling, but in reopening the whole question.

Remembering, however, that most students still accept Böhm-Bawerk's statement of the concept, we turn to a group of thinkers who would give other reading to it; and we shall confine our study to the leading representatives of two differing views on the question. This part of the Austrian writer's work, especially, was attacked by Professor John B, Clark [...].

In every-day speech and in the writing of economists there have been, since before the time of Adam Smith, two broadly marked ways of thinking of capital:

one views it as concrete goods, such as tools and machines; the other, as the money expression, or market value, of the goods, It is probable that no writer has long kept from the use of the term in both these ways, no matter what his formal definition. Frequently both uses will be found on the same page. A few writers only have chosen to frame their capital concept in accord with the second of these ways of thinking, Böhm-Bawerk has taken the former way, defining 
capital as the concrete goods; and in the interest problem he insists on the need of comparing goods of like kind and quantity. Clark declares this to be an error, and defines capital in harmony with the second way of thinking of it. He says, 'There is in existence a permanent fund of productive wealth, expressible in money, but not embodied in money; and it is this that business men designate by the term capital'. The concrete thing which make up this fund he calls 'capital goods'. In contrast with this list of goods he often speaks of this kind of capital as 'true capital', or 'pure capital', which, as he says elsewhere, 'resides in many unlike things, but consists of a single entity that is common to them all. That entity is effective social utility'. Again, he says: "Capital goods are... vanishing elements. True capital: "is abiding. Elsewhere he clothes his definition, which he calls 'the common and practical sense of the term', in these words: 'Capital is an abiding fund of wealth employed in production'. (Fetter 1900).

Even if one left out the subjectivistic connotation of utility as conceived of in the Austrian school, and brought it down to use value, the insurmountable problems that Clark's definition faces is that, contrary to his claim and hope, it constitutes no common basis of any two different, not to mention more, goods. The use values of a car and a toy car are very different, even if the objects themselves may look similar. The more so, if one assumes a subjective notion of utility, since the pleasures of a driver and a child playing with toys are incomparable. Therefor, the only substance that is common to a diversity of commodities is labour.

The relevance of the point on incommensurability is evident from Fetter's comment: "Böhm-Bawerk defends himself vigorously against the charge of "side-tracking" the theory of capital in defining the concept as he had done.

The controversy turned about the phrase 'goods of like kind and quantity', and the question as to the real nature of the comparison of present and future Goods" (1900). And his next remark underscores again the importance of a proper understanding of the relation between capital and property discussed above; "Clark gives this narrower content to the term 'capital,' confining capital to 'material forms of wealth that do not directly minister to consumers' wants', and does not make a place for acquisitive consumption goods" (Fetter 1900).

And it is again the aforementioned relation that Fetter's criticism against the Austrian economist is concerned with: "Clark's explanation of the genesis of capital is inconsistent with his own concept. Land used productively - for example, a farm, a waterfall, a mine, any rare and useful natural agent - is capital according to his definition. In his earlier utterances, such a thing are in plain words included. In the later articles this is still the inevitable implication of the definition, 'a fund of productive wealth expressible in money" (1900). When a definite natural force functions as an agent of production of material goods, it is by the same token an object of ownership. This does not mean, however, that its worth is necessarily expressible in money. Quite the contrary, it is precisely due to the fact that what is misleadingly called "free goods", such as air or water, cannot be easily expressed in money, that many, if not most environmental problems arise. And another interesting problem with the notion of capital contested by Fetter is raised by his comment on Böhm-Bawerk' claim "The genesis of capital", we are told, "takes place by a process for which the good old term 'abstinence' is, as I venture to maintain, the best designation" (1900). And the extent of confusion around the concepts of capital and property is revealed in his otherwise corect observation that "This does not seem to give a place in capital to natural agents" (Fetter 1900).

And the subject of another comment is also useful from the standpoint of the ownership concept: "There are, we are told, two classes of accumulators: the typical capitalists, who save to make permanent additions to their capital; and the quasi-capitalists, who 'save sums now, intending to spend them later'. There is no place here for the unearned increment of a newly discovered mine, which to-day forms for many men the chief productive wealth expressible in 
money, If this is saving, it is a sense so unusual as to require a special explanation by the author; and it is difficult to see how it can consistently be given. There certainly would be no attempt to evade the real question by assuming that the dollars that bought the mine had been saved; for the mine may not have been sold, and, if so, it is irrelevant to the issue. If the definition adopted by Clark is consistently applied, there are necessarily many things forming a part of capital which never have been saved, and which never have called for abstinence, as Clark employs that term. In fact, Clark seems to show here, as did Böhm-Bawerk, some traces of the error of the labour theory of value, so difficult to throw off" (Fetter 1900).

The claim that the use of the term "capitalist" is indicative of an adoption of the labour theory of value is an overstatement. In terms of ownership, it is more important that the author in question in effect blurs the distinction between ownership of capital and ownership of savings, and his criterion employed to distinguish the real from quasi-capitalists is from this standpoint irrelevant. One can, however, differentiate real and formal ownership of capital (ownership of savings) on the basis of several criteria, such as a given amount's comparison with what is needed to establish a plant, the reference of what is yielded by a given capital to the socially average value of labour power, etc. The level of expenditures mentioned in the above-cited passage does matter only if what is purchased is luxury goods easily convertible to real capital in the form of a going concern.

Further, Fetter's aptly calls attention to the above-mentioned confusion:

Clark would seem to err by extreme statement in making it in the nature of capital to be a 'permanent fund', 'In creating capital, we put the personal good away from us forever... An addition to the social fund of perpetual capital is brought into existence'. 'Nothing generates capital that does not add to the permanent fund of invested wealth'. 'True capital... is, in the absence of untoward accidents, perpetual, and yields perpetual fruits'. Many other expressions emphasize the same thought. Now this evidently does not apply at all to the author's quasicapitalist, who saves to spend later.

That, of course, is why he uses the term 'quasi', which evades the issue. Either such savings are capital (in which case why quasi?) or they are not capital, and may be omitted from the concept. The author, after stating that a part of the accumulation of capital is due to these quasi-capitalists proceeds as if there were none such. If better or more tools and larger stock were accumulated, and were then allowed to deteriorate while in use without being replaced, our author must certainly call them capital while they lasted; and, if so, the element of permanency is no essential part of the capital concept. Indeed, if a fund of productive wealth must be permanent to be capital, we cannot be sure that there is any such a thing; for we have not the gift of prophecy, and all human interests are fleeting. Clark himself says, 'Capital... normally will never perish'; but 'this is not saying that no capital ever perishes in fact'. This says clearly enough that permanency is not an essential mark of the concept, and makes meaningless both the word itself in that connection and a number of sentences, besides those quoted, in which this feature is emphasized as a vital mark of the concept. There is a valid thought in his contention, but it is not that capital is in its nature perpetual. There is ambiguity in the phrases "increase of capital" and "decrease of capital," because they may mean either some of the parts or the whole. A part of capital may perish while the total amount of capital is preserved or even increased. Clark would confine the expression to the whole of capital, and objects to the form of statement 'capital is destroyed' when the value of the concrete goods is passed on to other goods. But what of the cases where the total value is not preserved? The zeal of his attack carries him to an extreme and untenable expression. (1900).

Both economists involved are apparently not aware of the division of capital into constant and variable (which categories apparently go beyond of the confines of Clark's purported 
knowledge of the LTV), and, even more relevantly in the present context into Fixed capital which comprises the buildings and machinery that are not consumed entirely in the production process, and circulating capital, that is, the raw materials and labour power.

It is interesting to note that the critic is so keen to detect and possibly eradicate any trace of the labour theory of value that he overlooks his own sins to the same effect. He expands, namely, on Böhm-Bawerk's opinion [which to his mind] commends itself when he says - it is a 'figure of speech' that is "misleading" to say that the real wages, consisting of 'consumption goods' revived to-day for work done on goods not to be completed for years, are the "true and immediate fruit' of, e.g., the tanner's labour. To the tanner, of course, they are the "immediate" and only fruits, since they are all he gets for his labour, The question is, does it seem logical and expedient from the general standpoint in economic discussion to consider and speak of them as the 'true fruits' of that day's labour? The expression chosen appears to say merely that these things express the present market value of the labourer's services; that is, it is a roundabout and somewhat whimsical way of stating the truism that they are the man's wages (Fetter 1900) to which Fetter adds that:

Further, it may be urged that the inaptness of this expression is more apparent when something other than subsistence goods are considered. In the example chosen of the tanner, it is at least debatable whether it is best to call the shoes he gets to-day the "true fruit" of his labour. But in the case of the labourer receiving food and clothing for digging a canal or working on a marble palace, it is straining the point further to use the expression.

If here, too, his wages are called the "true fruit" of his labour, it still appears that the peculiar power ascribed to capital is due only to one part of capital, the finished consumption goods. No matter how large a stock of capital in the form of machines, buildings, and raw materials may be on hand, if there be no stock of finished goods, labour and its results are not synchronized. (c) A further objection to this way of conceiving of the nature of capital's work is that it would, if true, be applicable only to 'produced' forms of capital. As indicated by the phrases 'industry and its fruition', 'labour and its fruits', it implies vaguely the labour theory of value as to the origin of capital. The picture of labour continuously flowing into the reservoir of capital and consumption goods at the same time flowing out is not satisfactory as applied to products; for it implies that the inflow of a quantity of labour forces out consumption goods whose quantity is determined or measured by the quantity of inflowing labour. The value of consumption goods flowing out, however, is greater in varying degrees than the value of labour flowing in; and it is only through their values that we can compare at all the quantities of the two streams (Fetter 1900).

An awkward question immediately arises: what is the source and nature of this augmented value? And with it a clear sign of the LTV shows up. Going further, we now turn to the notable contribution of Professor Irving Fisher (Fetter 1900).

Then we are told that "he believes that a mistake has been made as to the real character of the problem, that it is not one of the classification of wealth, and that unavoidable difficulties attend every effort to delimit capital from 'other wealth', [and he contends that: note - J.T.] capital should be taken to mean simply all wealth at a point of time. It is contrasted not with other wealth, - for that category is exhausted, - but with the same wealth as a flow during a given period, and at a rate. The contrast, then, is between a stock and a flow, and still more important 'between stock and rate of flow'. [...] To grasp more fully the import of this radical proposal in economic terminology, let us note in what regards it differs from the conceptions we have been considering.

(1) Its content is wider than that of any foregoing concept, Böhm-Bawerk excludes all natural agents and most consumption goods from his wider concept, private capital, and excludes the 
other consumption goods used in acquisition from the narrower concept of social capital. Clark appears at first to include all natural agents, though excluding all consumption goods, then treats capital as if it originated only in labour, and did not include natural agents, and finally mystifies us by his contrast of capital goods and pure capital, leaving us in doubt whether he would include any concrete things as such. Fisher's concept takes them all in, sweeps down the wall between the old concept of capital and consumption goods on the one hand and natural agents on the other.

To my mind this suggestion is the most fertile part of Fisher's discussion. (Fetter 1900)

We tend to agree, but in a perverse way; Fisher's definition, namely, shows that contemporaneuous treatments of a multiplicity of capitals bear a family resemblance to at least certain economic ancestors in that both types of conceptions can indulge in over-inclusiveness (cf. this author's work 2013), as Fisher's all-embracing approach clearly does. And Fetter's further elucidation of the latter can only strengthen this view.

"(2) It agrees with Böhm-Bawerk's and differs from Clark's conception in considering that the concrete things should be estimated by physical measurements, and not in. The objection to Clark's view their money expression, in this regard, he says, 'is not that this summation of value is inadmissible, but that it is a secondary operation. Objects of capital are antecedent to the value of those objects... Wheat must be measured in bushels before it is measured in dollars"" (Fetter 1900). This shows that one reason for the aforementioned over-inclusive concept is his author's confusion of use value with value, which is apparent also in what follows.

It is also use value what is at issue in what according to Fetter "is a radical defect in Fisher's view. (a) It is true that wheat must 'be measured in bushels before it can be measured in dollars', but it must also be tested for quality. One will not value as highly a small apple as a large one, a sour as a sweet one, a rotten as a sound one. We could thus say that apples must be measured in sweetness before being measured in value. But an inventory of all possible measurable qualities, while helpful in estimating, would not itself express the amount of capital, for the things might after all have no value at all. (b) Though an intelligible description of the quantity of any single kind of goods could be made in such terms, yet the total quantity of many different kinds of goods cannot be expressed for economic purposes in a single sum excepting in terms of value. A capital account in which five pounds of feathers were added to a bushel of wheat and a yard of cloth would give a curious total. (c) Fisher is inevitably betrayed into inconsistency when he Comes to estimate the quantities of wealth, and express in percentages the relation between the stock and rate of flow, for this can be done only by comparison of values (Fetter 1900).

Indeed, as suggested above, the fact that both a book and a bottle of wine satisfy human wants makes a poor common denominator of the two. Fetter further claims that Fisher's "conception shares what I believe to be an error, common with it to both of the others, in that it makes the income of a community consist of 'streams... of the very same commodities' that compose the total capital. This, again, implies that all things of value originate in labour, and are on their way towards the goal of consumption goods: whereas many things, standing where they are, may be made to push other things towards that goal, though never getting nearer to it themselves; e.g., machines and natural agents" (1900).

That means of production should be distinguished from means of consumption, is incontrovertible. What follows subsequently is, however, much more objectionable than the faults of Fisher, as identified above by his critic.

Fisher means by income a 'flow of things' (material things), and rejects Mr Edwin Cannan's conception 'of income as a flow of pleasure', or satisfactions. The book-keeping of 
society will be thrown badly out of balance if services be not counted as a part of income; but, even if services be included as a part both of income and of capital at a point of time, there are still many things, as above indicated, that are a part of Fisher's capital only, and never are a part of the flow of income. They never have been made for consumption, and never will be fitted for consumption (Fetter 1900).

That services are able to satisfy people's wants, or to bring pleasure, to use the psychologistic language of the economist being cited, is again undeniable, but it will be interesting to see how this psychological interpretation squares with the point, so strongly stressed by Fetter, that means of production and natural agentsiii should be included in the concept of capital.

However, Fetter's final objection makes perfect sense, as noted above, :'the term 'Capital' is made synonymous with wealth, and two good words are employed in the same sense" (1900). Fetter's further comments are apposite as well: "Fisher anticipates this objection, and recognising its validity, if the fact be true, defends by saying that wealth presents the two aspects of income and stock (capital), differences important enough to merit separate terms. This defence fails, if the point made in the preceding paragraph is sound. By wealth, Fisher must mean here 'all wealth'. As I have shown, all capital must be considered wealth, and all wealth capital by Fisher's definition, though all wealth has not been nor will all wealth become income. Wealth and capital thus are synonymous, while income differs from them not merely as an aspect, but in the group of goods which composes it. [...] Careful distinction between a stock of capital regularly employed, the turn-over in a business, and the income from a business have not always been made; and confusion has resulted" (1900).

An answer to our question raise above emerges from Fetter's discussion when he "goes on to formulate more positively a capital concept which will be free, I trust, from the many objections that have been considered" (1900).

But from our point of view the gist of the matter is whether it will be also able to successfully undermine our criticisms mentioned above.

The scholar under consideration takes as his starting point "the distinction between private and social capital [given by Böhm-Bawerk. [...] The failure to distinguish them, he thinks, is the chief reason for the 'false' productivity theory of interest. If the difference is not seen between capital, the source of interest, and capital, the tool in production, interest, he argues, is naturally thought to be due to productivity. But, if it is clearly seen that a part of interest-bearing capital is not a tool in production, then productivity cannot be the one essential explanation of interest. This point was evaded by Clark, $[\ldots]$ for he simply considers social or productive capital, and omits mention of acquisitive consumption goods; [...] but in his reply to Walker it is put very clearly. 'There is interest without any production whatever... I refer, for example, to interest on consumption loans and to the return on durable consumption goods, such as rented houses, pianos, and the like'. Private capital is, by his view, social or productive capital plus some other things, enjoyable and more or less durable products let for hire to the user. Of what importance is this class of goods that makes all the difference between the two concepts? He has here mentioned rented houses and pianos: the stock illustration is the masquerade suit let by the costumer. A complete list of these articles would include a very small amount of wealth compared with that in social capital, and, doubtless, very much less than that in the rest of consumption goods. Yet it would be wrong to claim on this account that it is not worth while to make a difference in the concept. Logical differences of any importance call for distinctions in concepts, no matter how slight be the quantitative differences" (1900).

The distinction between interest-bearing or loan capital and either constant or variable or e.g. commodity capital is essential, but the question is if the former notion is legitimately 
applied to such transactions as room letting, and the like. Irrespective of this criticism, though, (which we resume below), Fetter's distance to statistical fetishism, deeming relevant large numbers only is sound.

The point made above as well as a more broad issue of capital as linked to ownership comes back with a vengeance in Fetter's logical grounds for such a distinction.

(1) There is no need to make an independent conception on account of this group of income-bearing things, if an explanation can be given that will dispose of them in a simpler way. Here are two houses lived in by the owners in two neighbouring towns. They are called consumption goods, bearing no income. Owner A moves into another house, paying $\$ 300$ rent, letting his own for an equal sum. His house then becomes acquisitive capital. Owner B does the same, and his house becomes capital. Chance or choice leads each to occupy the other's house. Each, through a broker and without knowing who his tenant is, pays the other $\$ 300$ yearly, and both homes are capital. Shortly, they move back into their own houses, which at once cease to be capital; and the 'income' of each man is reduced $\$ 300$ (1900).

The above passage reveals, again, the aformentioned economist' confused view of the relations between capital and property that we have discussed above. If a person or family simply live in their house, then it is a personal property, whereas when it it is converted into a means of acquisition, it becomes private property, and these shifting socio-economic functions are neither strange nor uncommon.

Thus, the following conclusion of the economist being cited is only partially true because he conceives of goods as having a core immutable economic nature that cannot be altered by such peanuts as a change in ownership relations it is involved in: a thing becomes capital or ceases to be capital not became of any change in its physical or economic nature, not became it is more or less serviceable to the community, not became the use to which it is put is altered, but simply because the man who owns it does or does not happen to be the one who enjoys that me (1900).

Even more ambivalent is Fetter's elabouration on the preceding:

Böhm-Bawerk himself, in his interest theory, has given us a hint of the way such an absurdity can be avoided without the me of a separate concept, though he does not see the application possible here. The person who rents a house buys the 'material services' of the thing during a definite period. The whole value of the house is simply the sum of a long series of uses. To the logical eye, though not to the technical eye of the law, the tenant or user is the owner of the thing during the time, with only such conditions as will insure its safe keeping and return at the close of the period. It may be looked upon as a sale to the tenant of a use or a group of uses defined by a period of time, and with the agreement to return the use-bearer when a group that has not been purchased begins to mature. The value of the unpurchased uses does not appear in the transaction, but they are bound up with the use-bearer that is given and returned (1900).

So far, so good, the writer cited above should be even praised for distinguishing economic and legal ownership.Further on, however, the distinction becomes somewhat blurred.

The dancer is often compelled to deposit the price of the masquerade suit when he takes it out. After the ball is over, his subjective valuation having fallen, he is the gainer by returning it at an agreed price which to the costumer represents its worth as stock to him. The latter keeps such things in stock because there are, on an average, enough such sales to pay his trouble, expenses, and a return on that amount of stock. Such rented consumption goods, being owned for the time by the user, form, then, no exception to the general class of consumption goods. The income of the dealer or the house owner is explained as a profit gained in exchange, like that of any other retail merchant, and includes a payment for services, risk, and income 
from stock employed. To explain such transactions as the sale of a group of uses (which is actually the temporary sale of the use-bearer) is entirely consistent with Böhm-Bawerk's treatment of interest, and makes needless the elabourate distinction between private and social capital. [...] The distinction in question may then be attacked on the still stronger round that it confuses things economic and legal. It is based on an unclear view of the relations of economic and contract interest. Let us look at this distinction. Contract interest is the interest actually paid by one person to another as the result of an agreement. Economic interest is the advantage attributable to the possession and use of a thing during a given period. regardless of its ownership. There is economic interest when a man uses his own plough to raise a crop or his own storeroom as a place of business Now, in the case of all the things included under social (productive) capital, contract is based on and tends to conform to economic interest. In all such cases it is economic interest that we seek to explain logically through the economic nature of the goods. Contract interest is a secondary problem, a business and legal problem, as to who shall have the benefit of the income arising with the possession of the goods. It is closely connected with the question of ownership. Only by accident, mistaken judgment, or old agreements, can the contract interest connected with social capital continue when economic interest does not. The two are related as cause and effect. Yet in the case of the relatively small group of consumption goods let for hire there is in the current view here represented by BöhmBawerk only contract interest, there being supposed to be no economic interest on which it is based. The economist's problem in distribution is essentially an impersonal one, to determine the economic contribution regardless of the question of legal ownership.

Here, if it be held that there is no economic interest or contribution, we have an anomalous case where the final answer to the interest problem must contain a mixture of economic and legal elements. No solution of this contradiction will, I believe, be found short of the view that contract and economic interest are normally inseparable. By 'normally' I mean that no man contracts to pay interest, or, being free to choose, actually does pay it, unless he has reason to believe that he thereby will gain the benefit of what must be called economic interest of a somewhat greater amount (Fetter 1900).

The above-cited passage further compounds the above-mentioned confusion by adding a category of interest, which, we believe, should be restricted for loans in money; in the case considered above one has to do with a material consumer good and not with money which, when it is transformed into means of production, becomes money capital yielding interest.

Marx makes it clear (The Grundrisse, Notebook V) that "credit in any developed form appears in no earlier mode of production. There was borrowing and lending in earlier situations as well, and usury is even the oldest of the antediluvian forms of capital. But borrowing and lending no more constitute credit than working constitutes industrial labour or free wage labour. And credit as an essential, developed relation of production appears historically only in circulation based on capital or on wage labour".

Another similar enunciation clearly shows that the parent Capital suffers from the same flaws as its baby capitals virtually all of which are over-stretched, step beyond their proper bounds. The aforementioned economist sums up his objections against the concepts of private and social capital discussed above. According to Fetter, the distinction between them rests on a supposed difference in the interest-bearing character of different groups of consumption goods. This difference can be explained in a simple way that makes needless an additional concept. In these concepts the interest-bearing quality is confined to the conventional production goods and such consumption goods as yield contract interest.

Many actions connected with 'consumption goods' are left unexplained. The interest phenomenon is found wherever there is abiding value. iv 
Our conclusion, then, is that the distinction between social (or productive) and private (or acquisitive) capital rests on illogical grounds. (2) The distinction between them rests on legal, not on economic grounds, and involves a confusion of economic and contract interest. (Fetter 1900).

In actual fact, it is above all Fetter himself, who is guilty of the sin he attributes to others. Profit, ground rent, and interest on loan capital are all different forms of income which, however, can be fully articulated and comprehended only within the framework of economic ownership. On the other hand, Fetter's claim that the economic and legal relation of ownership are merely two sides of the same coin is, just as its justification, naive and/or biased. Taking for granted that the debtor incurs his or her debt always and necessarily of her free will and in the best interest does not take account of the innumerable cases of economic compulsion, as opposed to legal freedom. Thus, the economist concerned ends up questioning the very distinction he boasts about a few sentences earlier. And there are, of course, much more cases of the said discrepancy, e.g. in the black lumpeneconomic world wherein all economic transactions are by definition illegal.

It is the final part of Fetter's argument, however, that appears most problematic. He comes up with another objection to the distinction between social and private capital; namely, that it involves a wrong conception of the nature of income. I shall maintain that income must be looked upon as a series or group of satisfactions, not as a series or group of material things. Though scattered authority may be found for this view, it is at variance with the views alike of Böhm-Bawerk, of Clark, and of Fisher, as well as those of the great majority of economists, and requires explanation and defence. The thesis is that the economic goods which are "produced" either by human effort or by the material services of goods must, in their last analysis, be looked upon as satisfactions. [...] the view is one peculiarly in harmony with the psychological treatment of value which Böhm-Bawerk favours. Indeed, it seems to me the view to which that value theory logically and inevitably leads. [...]

The view suggested looks upon all material goods as means of production or capital, their value being derived from the states of satisfaction to which they minister or which they enhance, Böhm-Bawerk's objection to this lacks validity. He says: 'Any unbiassed person can see how unfortunate this is. Without due cause it obliterates the very important distinction between the production of goods which satisfy want and their consumption. It christens, for example, the idler as a zealous producer, always thinking how he may produce the personal goods of satiety, of ease, of contentment, and so on'. It needs only to be replied to this that the idler in such case would be wrongly christened. The term 'means of production' must be confined to objective means of producing a subjective state, not to subjective states, to Buddhistic dreams that unite the dreamer with Nirvana.

The pleasure of basking in the sun is a fact of which economic theorists must take note; but that pleasure can be secured usually by the use of free goods, and thus is not an economic satisfaction, it becomes an economic satisfaction when it is conditioned on the control of some scarce material agent or can be secured only by effort. The test, then, of economic personal goods or satisfactions is dependence on either objective things or persons, or on reaction against the outer world by the man seeing the satisfaction. If the objection of Böhm-Bawerk is urged beyond the extreme and inapplicable example he has given, and is applied to the personal services of one man for another, it leads to the old and abandoned distinction between productive and unproductive labour. We do christen many men 'as jealous producers because they are producing the personal goods of satiety', in other men. Such services must be counted as ephemeral forms of wealth, enjoyed or consumed at the moment of their production. This is no more obliterating the distinction between production and consumption than eating a hot cake 
fresh from the griddle obliterates that distinction. The two things are as logically separable in thought when they occur simultaneously as when a second or a decade intervenes. We have ceased to consider it essential to 'productive' labour that it should be first embodied in material form, however fleeting. The same untenable distinction is adhered to almost universally in the case of the services of material goods. Their productive contributions must be put on the same basis as those of labour, to be measured by the intensity of the wants they aid in satisfying and the psychic states they help to produce. The house of the mill-owner is, logically considered, producing directly, his mill is producing indirectly; for only after a devious journey will the contribution of the mill reach its goal in the satisfaction of wants. Our economic book-keeping can be made to balance only when real income be looked upon as a flow of pleasure in all cases, not as a flow of goods in some and a flow of pleasures in others, as is done generally now (Fetter 1900).

It is paradoxical that a criticism against this extreme for of psychological subjectivism should come from a representative of Austrian school which itself subscribes to those very principles. Anyway, Fetter's view transforms all production of material goods(including means of production, since the latter generate pleasure indirectly), let alone services or immaterial work into a gigantic hedonistic enterprise. It is also interesting how the aforementioned thinker's imagination allows him to calculate, or even compare, those by by definition subjective unique states. No less far reaching are other conclusions he draws from the above premises.

This view makes possible the correction in the concepts of private and social capital of another fault which calls for our fourth and last objection to this part of the almost universally accepted treatment. The fault is this. Interest is looked upon as connected with a special class of goods: it must be recognised to be connected with everything of value.(65*) The value of anything is built up on its uses or services to men. Wherever there is a postponed use, that use is subject to a discount. Its present worth is less than its worth will be at maturity. Consider the case of consumption goods. In the orthodox view a bushel of apples, kept by the grocer from fall till spring, is capital, and normally shows economic interest in enhanced value. Bought in the fall and stored in the cellar by the housewife, it is a consumption good; and economic interest is absent. But that early purchase can only be rationally explained as we take account of the increment of value on the apples thus stored, and this is economic interest. Larger purchases in advance effect, of course, economy of labour, and bring an additional motive to make them; but this is not saying that the whole saving is wages, and that no interest is gained.

The radical consequences of this view are evident. It erases all distinction between the essential economic character of so-called productive and consumption goods. The term 'consumption goods' may still be conveniently retained to mean, as at present, the material good in its final form in the hands of the one intending to use it; but it ceases to be an essential economic category. Every material good and every human service has value only as it is a condition to the satisfying of a present or prospective want. The abiding value of the diamond is built on no more substantial foundation than its flash and sparkle.

Market values are the capitalized economic contribution of objective agents to psychic states: and these states are the final, highest, only essential economic products. (Fetter 1900).

Given the premises, it is only logical that any distinction between means of consumption and means of production should be completely erased, only that it is at odds with his previous assertion to the opposite effect: "the distinction between consumption goods and the true instrument of production is essential" (Fetter 1900), as well, methodologically, with his complaint that "Careful distinction between a stock of capital regularly employed, the turn-over in a business, and the income from a business have not always been made(Fetter 1900). Instead 
Fetter chooses a rather peculiar line of defence by twisting everything round: "A great advantage will be gained when, dropping unessential distinctions, we are able to save the term from double meanings" (1900).

Besides, another interesting thing is the compatibility of the concept of interest, which is usually couched in money terms, as applied to value understood in entirely subjective sense, as in the above-mentioned case of apples. Unless, of course, one is prepared to take at face value Fetter's purely linguistic expedient: "The income that needs to be explained by economic theory is the flow of objectively created pleasures coming to the individual and the community" (1900).

Thus far we have identified a range of different guises in which Ludwik Petrazycki's (over-inclusive) fallacy manifests itself. This list, extensive as it is, is far from being exhaustive, as the final part of Fetter's deliberations persuasively shows.

He is not happy with Böhm-Bawerk's definition, which in his opinion in common with nearly all usage, limits the conception of capital in another way; namely, with regard to its origin. As well private as social capital consists of a 'group of products'. In the foregoing, I have widened the term productive as applied to consumption goods; but the products there mentioned (feelings, satisfactions), being ephemeral, do not increase the capital stock existing at a given moment. And, being final products, these states of feeling cannot be used in further economic processes, and do not, therefore, widenv the definition Böhm-Bawerk has given us. The test so far applied to these concepts has been alone that of economic function. Confining capital to material 'products', as does Böhm-Bawerk, applies an additional and distinct test, that of economic origin, - and must be separately examined.

The purpose of the adjective 'produced' in the phrase "produced means of production' is to exclude land. While conceding that there are some good reasons for including land under capital, Böhm-Bawerk declines to do so for the reasons which we may enumerate, as follows:

1. Land is immovable. Capital is, for the most part, movable.

2. Land is a gift of nature, Capital is a result of labour.

3. Land cannot be increased, capital can be.

4. The social and economical position of the landlord is essentially different from that of the capitalist.

5. Property in land and property in movables are justified on essentially different grounds, and they are commonly attacked by quite distinct people.

6. Land is the special agent in a kind of production [agriculture?] that is economically distinguished by many important peculiarities.

7. The income from land differs in many ways from income from capital.8. Using capital for all material means of acquisition leaves us no name for produced acquisitive instruments. 1

8. Popular usage does not put land under capital, but opposes the two.

9. Usage does not apply the term "interest" to the income from land.

He concludes that "it is most convenient to keep land quite distinct from other kinds of Productive wealth," and that "there is a considerable balance in favour of defining capital as the 'produced means of acquisition,' and against the inclusion of land." (Fetter 1900).

Fetter sets out to dissect the above-cited list:

Of this formidable list it must be said that not a reason given, considered singly, is free from flaw, some are quite mistaken, and collectively they are not conclusive. The worth of 1 is destroyed for purposes of definition by the limitation "for the most part." It is not that a 
definition may not be based on a difference in degree, where qualities grade off from one extreme to another; and, if something of importance depends on the degree, it may often be expedient to draw a line of division more or less arbitrarily somewhere. Here, however, it is not so. Things, like houses, ditches, trees, that are as firmly fixed as the soil itself and whose value would be quite lost if they were moved, are, without a question, included in capital. (1900).

The aforementioned criticism highlights, once more, the critical importance of the notion of socioeconomically understood ownership; from the vantage point of the latter it is evident, firstly, that wild trees are natural objects, whilst those grown by men incorporate human labour in them, just as land used in agriculture does which affects the socio-economic character of its fruits. But this does not alter the fact that it is e.g. the fertilizer rather than the soil itself that should be treated as capital, as, on another example, is explained by Marx, "In agriculture the land under cultivation cannot be increased without the advance of more seed and manure. But this advance once made, the purely mechanical working of the soil itself produces a marvellous effect on the amount of the product. A greater quantity of labour, done by the same number of labourers as before, thus increases the fertility, without requiring any new advance in the instruments of labour. It is once again the direct action of man on Nature which becomes an immediate source of greater accumulation, without the intervention of any new capital" ("Capital", v.1, ch. 24); or elsewhere, ("Theories of Surplus Value, Notebook VI): "in agriculture [...] natural fertility of the soil can act like an increase of fixed capital-i.e. relative surplus labour can grow-without the amount of necessary labour diminishing".

Fetter goes on with his diatribe:

Turning to the other part of the statement, that land is immovable, it is found quite as untrue. Parts of land are shifting from day to day. It is usual for those who follow this definition to consider that a thing ceases to be land and becomes capital the instant it is moved by man's agency or effort; but to appeal to this to prove the point is to confound "unmoved" with "immovable." No matter is immovable. To say that "land" means something that has not been moved by man begs the question, and this is evidently an untenable definition of nature or material agents. (Fetter 1900).

For one, this is a peculiar notion of "material agents" in whose terms a machine tool, a ladder, let alone a truck would be understood as somehow immaterial. Second, there is a lot of sophistry in this argument, and, third, Fetter forgets that he's just referred to trees that are certainly natural agents, after all, as "firmly fixed".

Without delving into the question of to what extent his claim is valid, we may note Fetter's inconsistency with the usage of his own: "Reason 1 in the list appears to be an illogical use of reason 2, it being falsely assumed that results of labour are necessarily movable in the relative sense in which we can use that term of material things, and that gifts of nature are immovable. No such parallelism exists, and the two reasons are often in conflict".

Emblematic of not only this specific, but a broader economic community's approach to class and property relations is his judgment:

We take up 4 and 5, which appeal to social and personal grounds of distinction, not to economic and impersonal ones. Here is, one more time, a confusion of the political or legal question of ownership with the real economic question, the function performed or contribution made by material agents. This difference, moreover, in the social position of landlord and capitalist, so emphasized, can be shown to rest on accidental historical grounds which we cannot now discuss. Again, the emphasis of this difference is largely due to the misleading terminology which is under discussion. (1900).

Ownership and class are by any means exclusively matters of terminology. And the thesis that a specific system of class relations is a product of historical development is universally 
valid, and by any means applies merely or particularly to the landowning class. Secondly, whilst it is perfectly possible that in this or that historical conjuncture, some members of the bourgeois class acquire land, or, conversely, a portion of the landholders' class run their estates in a capitalistic manner; but this merely means the emergence of a mixed class, but by any means obliterates the specificity of a given agricultural property in question wherein, as Marx noted.

Capital Vol. III Part VII) the circumstance that 1) rent is limited to the excess above the average profit, and that 2) the landlord is reduced from the manager and master of the process of production and of the entire process of social life to the position of mere lessor of land, usurer in land and mere collector of rent, is a specific historical result of the capitalist mode of production. The fact that the earth received the form of landed property is a historical precondition for this. The fact that landed property assumes forms which permit the capitalist mode of operation in agriculture is a product of the specific character of this mode of production. The income of the landlord may be called rent, even under other forms of society. But it differs essentially from rent as it appears in this mode of production.

Marx's comments are more than enough to question Fetter's view who "contests the statement that property in land movables" is justified on essentially different grounds. They must be, and are by most political theorists of to-day, justified on exactly the same ground." (1900).

There is a huge difference between the passive rent-taker and the classic capitalistic enterpreneur who runs his or her business in connection of which he may be entitled to extra surplus value that is a reward for his risk, good investment decisions, etc. Whilst at some level of abstraction one can indeed claim that all forms of private property possess a common core, this must not obliterate their important peculiarities, which can only be overlooked if one is not familiar with a socio-economic approach to ownership, and, thereby divorce the social from economic, as the economist under consideration does.

His ignorance of the aforementioned theory surfaces again in his criticism of the fallacy of thinking of land as a field used for agriculture. It must be said, first, that land, in the sense of the word under discussion, - i.e., natural agents, - is an indispensable agent of the milling industry, carpentry, and every other art, as well as of agriculture.

To call land the "special" agent of agriculture because that part of land which consists of fertile soil is necessary for plant life is to make a very crude distinction, based on no logical principle. At most a difference of degree only is involved, in that a larger area is usually needed to produce a given value of food than is needed to produce that value of other things; but the reverse is frequently true. (Fetter 1900).

That the worker at the shop floor, and the entire factory building must stands somewhere does not make land an active factor of production; it is, however, an agent of agricultural production which is inextricably linked to its peculiarity as a property.

Thus, no matter whether Fetter is or is not correct in attributing to the Austrian the following inconsistency: "When Böhm-Bawerk comes to explain interest from durable goods, he refutes the statement that income from land differs in many ways from income from capital, and, 'obeys many distinct laws of its own'. He then finds that the two incomes 'have one common final cause'. Land rent is nothing but a special case of interest obtained from durable goods"(1900), the proposition at issue is untenable as it implies, as has been repeatedly indicated above, the blurring of the differences between the two forms of income concerned and thereby, corresponding property relations.

Böhm-Bawerk's unremitting critic argues further that popular usage and economists, even those who favour Böhm-Bawerk's terminology, in many cases class land under capital, 
speaking of the investment of capital in land, and reckoning the land with the man's capital thereafter.

So, when a loan is made in money, we are always told that the thing really borrowed is what the money buys: if machines, then it is really these for which interest is paid; if a farm, then it is this for which interest is paid. The moment you give the money aspect to the loan, no attempt is made to distinguish between the income from land and the income from other material agents. (Fetter 1900).

Once more, that one can invest in land, which has already been mentioned above, does not detract from the socio-economic distinctiveness of this type of property.

Fetter's final and supposedly fatal blow is levelled against "the parent of all the other reasons[for] the errors just considered [:] the labour theory of value" (1900).

He has in mind his adversary's statement that "capital is partly and, indeed, as a rule, it is principally, 'previous labour'; for the rest, it is valuable natural power stored up for human purposes" (Fetter 1900).

Fetter is not satisfied with the Austrian economist's "limitations on the proposition": "The asserted 'law,' that the value of goods is regulated by the amount of the labour incorporated in them, does not hold at all in the case of a very considerable proportion of goods; in the case of the others, does not hold always, and never holds exactly. These are the facts of experience with which the value theorists have to reckon" (1900).

As Fetter notes, the same idea appears elsewhere. "Capital - to keep the same form of expression- is 'stored-up labour,' but it is something more: it is also stored-up valuable natural power (1900).

Fetter argues further:

The part attributed to natural powers reaches at times the vanishing-point as BöhmBawerk shows; but he does not draw the obvious inference that the part of labour reaches at times the vanishing-point, and that many products, many things classed by him as capital, are exclusively 'stored-up' natural powers. Why continue to apply the phrase 'products of labour' more than "products of nature" to those things which owe to labour proportions of their value varying from all to nothing? Where there is no labour, would Böhm-Bawerk cease to call the thing capital? Certainly not, must be the answer, if that is the only difference. (1900)

The source of Fetter's evident error is-in Marxian terms-he conflates use value with value. Whilst there is no denying that many natural processes are co-productive of a given material good's useful properties, and, moreover, increase labour productivity, it does not follow that it is them and not labour, more precisely abstract labour that create value and surplus value. The derivation of value from labour was attempted by many before Marx, but his discovery was the distinction between two types of labour: concrete and abstract tied to, respectively, use value and value from omitting of which arise many errors and misunderstandings.

Another necessary distinction is one addressing Fetter's aforementioned objection; the LTV does not apply to unique goods whose price, as in the case of Monet's paintings, is determined by their utility to their buyers.

And another critical in intent claim advanced by Fetter to the effect that "Some capital, things treated as such by Böhm-Bawerk and others, is not the result of labour at all, - for example, the meteoric lump of gold, the annual crop of fruits on an untied field, the yield of a mineral spring"(1900) stems from his lack of clarity as to the relation between capital and ownership that has been repeatedly pointed out above.

This shortcoming, in conjunction with our old friend: the leaping fallacy is evident in the claim that the idea of capital is carried over to all things of value, regardless of the question of the origin of the good, Böhm-Bawerk illustrates this usage frequently, for example, when he 
speaks of the 'capital value of land', vi and, again, in making use of the word 'capitalization' in explaining the value of land and interest arising from it.vii The business man, followed by the economist when he comes to discuss practical problems, starts with the thought of a man with a sum of money to spend for buying goods; and this buying is called: 'investing', his capital, or, as the word originally meant 'clothing', the money in the form of other material things. When the money is thus 'invested', it may be in the form of machines, buildings, lands, products on which labour has been employed. If the investment has been fortunate, we say, comparing the values with the value of the money expended, that the capital has increased. Now there is of course some danger of confusing capital with money, but no more than in every case where money is used to express the value of other goods. What is the capital? Either the money or the thing whose value is expressed in money, Money is itself a concrete thing, one in which the value of other things is expressed. It is this expression and measurement of market value which is the essence of the capital concept in much business usage, as well as in most economic discussion, no matter what may be the formal definition. This must be recognised in our definition. Capital, in our conception, is an aspect of material things, or, better, it consists of material things considered in one aspect, - their market value. - It is under this aspect that men have come more and more to look at wealth. The growth of a money-economy has made it more and more convenient to compare and measure the value of dissimilar things in terms of dollars.

Things are thus capitalized. A writer, tracing the development of the wealth concept, has well pointed out that at one time wealth was looked upon as consisting of things of use to the owner, lands, flocks, herds, - use-values, to use the old phrase, - but that now it is looked upon as made up of things having exchange value, estimated in terms of the general standard of value in the community. viii [...] The term 'property', again, is loosely used in place of wealth or capital, but can be clearly distinguished from them as the legal, not the economic, aspect of valuable material things. In short, 'property' has as its essence the idea of legal right; and in connection with material things the important right is that of control. Ownership is simply a greater or less degree of control, The term " property," meaning legal rights of control, is broader; that is, extends to more things than the terms 'wealth' or 'capital', for it includes patent rights, legal monopolies, valuable agreements from men to do or not to do certain things, all having the common feature that the value is not attached to or connected with or attributed to a material thing, but is due to the legal right to control or limit some person's action. It seems inadvisable to try to make the content of wealth as large as that of property by considering that men become wealth to the degree that their rights are limited in the interest of others.ix To illustrate the use of the terms "wealth," "capital," and "property," we would say that a stock of goods is wealth, it is (or it represents) a capital of $\$ 10,000$, and it is the property of Jones, and the property is worth $\$ 10,000$. If Brown holds a mortgage of $\$ 5,000$ on the property, however the lawyers may look at it, we must consider that Jones's property (or right) is only of the value of $\$ 5,000$. The property of Brown and that of Jones are both found within the capital of $\$ 10,000$, and in total value cannot exceed it. The value of the property owned never can exceed the capital that is the object of the legal right. Many absurdities in our laws of taxation have resulted from confusing the economic view of wealth with the legal question of ownership, and of confusing, still less excusably the mere paper evidences of legal rights with the wealth to which those rights apply.

To restate the definition that has here been arrived at: Capital is economic wealth whose quantity is expressed in a general value unit. It is used as applying to a single thing or to a group of things. There is no place in it for the distinction, the inconsistencies of which have been discussed, between individual and social capital. We do not call the services of thing that minister directly to satisfaction unproductive while calling the personal services of men 
productive, even where nothing material results. We do not retain the distinction between consumption and production goods as essential in economic discussion. All valuable thing of more than momentary duration are "intermediate goods," are capital, in that they are valuable became designed to satisfy future wants. While the definition thus sweeps away any limitation on the content of capital became of a difference in future me, it likewise sweeps away any limitation because of a difference in the origin or source of its value. Capital is not thought of as made up only of goods whose value is the result of labour. It has been shown that the prevailing distinction between 'natural agents' and 'produced agents' of production involves radical defects of logic and is practically not maintained. This definition is emancipated from the false labour theory of value. (Fetter 1900).

Well, it at the same time is emancipated from any chance of faultless reasoning. The traces of the latter are present in the distinction between use and exchange values in the context of ownership which has been underlined above. When an object is exchanged into money, it is no longer personal, but becomes private property. The distinction, however, between legal and economic ownership is misconceived. Fetter's example of mortgage is a case in point insofar as the property in question is in fact co-owned by the creditors, and it is ownership in economic terms, of course. Moreover, ownership and control, disposal, or decision-making by any means mean the same thing, insofar as ownership is by definition different from its preconditions or consequences to which the latter relations in fact refer. In Fetter's treatment, the relationship of capital to money is indeed ambiguous. Not all sums of money can be classed as capittal; in principle, this refers only to money capital as initiating the process of production or other private economic activity, and money similarly yielding more money in the case of converting it into a loan. Whilst the ultimate source of all those kinds of income is to be found in surplus value, only those who own means of material labour and set them in motion by employing other people's labour power, do appropriate the surplus value produced by their workers. In other cases, whether in commerce, finance, or services, private ownership of economic action only enables their owner to share in the social pool of surplus value.

The preceding suggests what is the crucial gap in the reasoning of Fetter, and many other non-Marxist economists, for that matter. They are not aware that capital is not a thing but, rather a determinate social relation, belonging to a definite economic formation of society, "which is manifested in a thing and lends this thing a specific social character. Capital is not the material and produced means of production (...). it is the means of production monopolised by a certain section of society, confronting labour-power as products and working conditions rendered independent of this very labour-power, which are personified through this antithesis in capital" ( Marx, "Capital", v. III).

The following criticisms have much broader relevance, they apply to the previously considered deliberations on capital as well. "capital is equated with 'efficient machinery' and the 'application of science to industry'. Capital is simply, for Joan Robinson as for all political economists, 'stored up labour'. On this view, as Marx long ago indicated, the first capital was the first stone picked up by the first savage. Second and this is a reflection of the first error capital and land are lumped together. A social relation is joined up with the basic prerequisite for the production of wealth in all societies. Third, the point about the productivity of capital is completely misunderstood. [...]

Marx saw labour as the 'creator' of value. Abstract labour creates value: that is a definite social form of labour produces and reproduces definite social relations of production. But this does not mean that the 'objective factors of production' are to be denied any form of 'productivity'. On the contrary, to the extent that these factors raise the level of production they are certainly productive, but productive of use-values (a category which Joan Robinson 
continually confuses with value). Marx is explicit on this point: "The use-values, coat, linen, etc. i.e. the bodies of commodities, are combinations of two elements - matter and labour. If we take away the useful labour expended upon them, a material substratum is always left, which is furnished by Nature without the help of man. The latter can work only as Nature does, that is by changing the form of matter. Nay more, in the work of changing the form he is constantly helped by natural forces. We see, then, that labour is not the only source of material wealth, of use-values produced by labour. ("Capital" v. I).

Pilling draws attention to the circumstance that Capital is, however, productive in a quite different sense. It is productive as the dominant social relation of modern society. For Marx capital was productive because it was able to 'enforce surplus labour' on a scale far surpassing any previous social relation. It is not, therefore, a question of obliterating the distinction between capital and labour. As Rosdolsky has said in exposing Joan Robinson's confusion, labour is the horse producing surplus value, capital is the whip across its back. Hence for Marx productive labour is labour which when exchanging against capital produces surplus value. Here 'productive' has an entirely social meaning - concerned with man's relationship to man and is not to be confused with the material relation of man to nature. (1980).

And the same researcher refers, only that in broader terms, to what has been noted above; Marx shows, to give a specific instance of the results of this approach, that while capital cannot exist independently of money, equally it cannot be reduced to this lower form. There have been many mistakes in the history of political economy arising from efforts to separate out completely the economic forms which, in their process of development, actually constitute a unity. The notion that the contradictions of capital could be overcome through the abolition of money provides one such example. But equally serious mistakes have occurred when higher economic forms have been mechanically reduced to their lower forms when, for example, capital has been confused with one of its forms such as money capital. Marx's dialectical method alone enabled him to avoid these mistakes. His conclusion: capital is value, but value of a peculiar type, namely self-expanding value; it is a social relation attached to things which appropriates surplus value created in a definite process of production, and it thereby continually reproduces both capital and the relation of capital itself.

The origin of this surplus value (which was taken as given by classical economics) was revealed by Marx without any reference whatsoever to individual capitals or the relations between them. Indeed, this point must be even more strongly put. To have dealt with the immediate form of economic relations (as they emerged in the sphere of competition) would have rendered impossible an uncovering of the process by and through which surplus value is extracted from the working class. In the form it takes as profit, surplus value seems to be produced in equal amounts by all sections of capital and as such capital appears to be the source of wealth, independent of labour.

It was therefore essential that Marx should disclose the nature of this 'capital in general' before he dealt with its specific, immediate forms and why capital in general is dealt with before its forms profit, interest, rent; these latter forms are explicable in terms of particular forms of capital. It is no accident that along with the notion of abstract and concrete labour, Marx considered this latter point to be one of the two best in his entire work. In short, it would have been impossible to get to the essence of what Marx calls the 'finished forms of capital' (G: 209) without this abstraction 'capital in general', or what Marx calls 'capital as such, capital in the process of becoming’ (Grundrisse) (Pilling 1980). 


\section{CONCLUSION}

It is fair to say that the relationship of capital and economic ownership has been demonstrated, a necessary caveat being that this hinges on a particular view of ownership, argued for in the first section.

\section{References}

[1] Berle A., G. Means (1969). The Modern Corporation and Private Property, New York: 20th Century Fund.

[2] Coase R., The Nature of the Firm, Economica 4(16) (1973) 386-405.

[3] Cohen Avi J., Harcourt G. C., Whatever Happened to the Cambridge Capital Theory Controversies? Journal of Economic Perspectives 17(1) (2003) 199-214.

[4] Fetter Frank A., Recent Discussion of the Capital Concept Quarterly. Journal of Economics, vi (1900) 309-416.

[5] Hayek F. (1989). Order With or Without Design?,: Selections from F.A. Hayeks Contributions to the Theory and Application of Spontaneous Order Compiled by Moldofsky. London: The Centre For Research into Communist Economies.

[6] Heller M. A. (2008). The Gridlock Economy, New York: Perseus Books.

[7] Marx K. (1967). Capital Vol. I, , New York: Progress Publishers.

[8] Marx K. (1939), Economic Works of Karl Marx 1857-61Grundrisse der Kritik der Politischen Ökonomie, Outlines of the Critique of Political Economy, Moscow: Foreign Language Publishers.

[9] Marx K. (1861-3). Economic Manuscripts: Theories of Surplus-Value, Addenda to Part 1. Moscow: Foreign Language Publishers.1939b. Notebook VI.

[10] Marks K., Marx K. (1980). Ekonomitcheskye Rukopisy 1857-61, Economic Manuscripts 1857-1861, part I. Moscow.

[11] Mises 1. (1936). Socialism: An Economic and Sociological Analysis, London: Jonathan Cape.

[12] Pilling Geoff. (1980). Marx's Capital - Philosophy and Political Economy. Chapter 2. London: Routledge.

[13] Poulantzas N. (1973). Political Power and Social Classes, London: Verso.

[14] Simmel G., (1990). The Philosophy of Money, ed. David Frisby, 2nd. Edition, London, Routledge.

[15] Simmel G., (1997). 'The Berlin Trade Exhibition', in Simmel on Culture, eds. David Frisby and Mike Featherstone, London, Sage S.

[16] Veblen T. (2001). The Engineers and the Price System. Kitchener, Ontario: General Books. 
( Received 16 December 2013; accepted 23 December 2013 )

\section{ENDNOTES}

${ }^{\mathrm{i}}$ More in (Tittenbrun 2011a; 2011b).

ii This applies also to human capital: cf. (Tittenbrun 2013).

iii Considering a key role of human labour in the production process, only those bacteria, types of energy, chemical processes, etc. should be considered the means of production that are consciously used or manipulated by those doing material work. In this sense e.g. rain is economically relevant, but does not constitute a means of agricultural production, except in currently rare cases in which it would be artificially generated for that end.

iv Yale Review, ii. 308.

${ }^{\mathrm{v}}$ For a more extended argument see (Tittenbrun 2011).

${ }^{v i}$ Positive Theory, p. 344.

vii Ibid., p. 348.

viii Charles A. Tuttle, in Annals of the American Academy of Political and Social Science, i, 615, ff.

ix Such a view is taken by Irving Fisher, Economic Journal, vii, 206. 